\title{
Volatility Spillover among Equity Indices and Crude Oil Prices: Evidence from Islamic Markets
}

\author{
Jihed Majdoub \\ Institut Supérieur de Gestion, Université de Tunis, Tunisia \\ Walid Mansour \\ Saudi Arabian Monetary Authority \\ Islem Arrak \\ Institut Supérieur de Finances et de Fiscalité, Université de Sousse, Tunisia
}

\begin{abstract}
This paper studies the volatility spillover between Islamic equity markets and oil prices. We use a sample of five countries from the Gulf region. The results show that there is a reduction in the volatility spillover, particularly for the Saudi market. This can be interpreted, in our opinion, in terms of the distinguishing features of the Islamic financial intermediation mode, which is more able to alleviate the transmission of shocks to domestic markets and ensure a better stability to financial markets. The new structure of volatility spillover has important implications for international investors with respect to portfolio diversification benefits and for financial policymakers regarding contagion risks and portfolio allocative policies.
\end{abstract}

Keywords: Volatility spillover, GCC, Oil price, Islamic finance.

JEL Classification: G11, G15, G32, E3.

KAUJIE Classification: A1, H1, I1, L41.

\section{Introduction}

The exploration of the volatility spillovers between the Gulf Cooperation Countries (GCC) oil-producing economies is of paramount importance because this region contains the largest producer of oil in the world, namely Saudi Arabia. In this article, we endeavor to study the volatility spillover between the equity market index and the oil price. Strictly spea- king, we aim at exploring whether the Islamic equity market indices interact with the oil price in the same way as conventional equity market indices do. In the recent past, several empirical studies have tackled the phenomenon of volatility transmission seeing its importance for policymakers and market participants. This issue has a variety of implications in 
terms of the dynamics and stability of financial markets, hedging effectiveness, portfolio performance, and international diversification.

Despite the diversity of studies, both in terms of econometric methods and data, there is a scarcity in the study of how volatility of Islamic equity markets interacts with the volatility of oil prices. Recent studies and policy reports show consistently increasing size and growth of the Islamic finance industry. For example, the recent IFSB's (2017) report indicates that the Islamic financial services industry's assets size amounts to about $\$ 1,893.10$ billion, as of the end of 2016. Islamic banking assets dominate the industry with a share equal to $78.9 \%$, followed by sukük issuances (16.8\%), Islamic funds (3.0\%), and takâful contributions (1.3\%). Most of the jurisdictions that are endowed with systematically important Sharíahcompliant institutions are located in the Gulf region and South-Asian countries.

The research question of this article aims at filling the gap in the empirical literature by exploring whether there is interplay between the volatility of Islamic equity market index and the volatility of the oil price. In other words, we will study the extent to which the volatility spillover of the Islamic equity index will be modified when compared to the volatility spillover of the conventional index. In order to reach this goal, we use daily data about market index returns and oil prices spanning April 1, 2011 to April 1, 2015. Our sample is made up of five economies, namely, Saudi Arabia, Kuwait, Qatar, UAE, and Jordan. Our results corroborate the fact that Islamic financial principles help in reducing volatility transmitssion and lowering volatility persistence. Our results constitute a clue for portfolio and fund managers because they can benefit from Islamic equity markets.

The remaining of the paper is organized as follows. Section 2 provides a review of the literature regarding the volatility transmission and crude oil and some basics of Islamic finance. Section 3 provides the econometric method used in this research. Section 4 describes the data and discusses the hypothesis while in section 5 we present the interpretation of results and some policy implications. Section 6 concludes the paper.

\section{Crude Oil and Islamic vs. Conventional Stock Markets: A Short Review}

This section discusses the extent to which oil is a major driver for GCC countries' growth and the related empirical studies that explore the phenomenon of transmission volatility. The main ideas that will be explored are supported by recent empirical findings and include the following: (i) the study of transmission mechanisms for optimal portfolio decisions; (ii) the performance of stock markets as a consequence of volatility transmission; (iii) the relation between oil price and volatility spillover; and (iv) the specificities of Islamic financial markets and the corresponding unique financial intermediation mode that stems from the Qur'ān and Sunnah.

\subsection{Background on volatility spillover and crude oil}

Oil has a great importance in the global economy today. Several journal articles have examined the role played by the oil price. Understanding of return and volatility spillovers between the GCC and oil markets is of great importance because the GCC are the major players in the global oil market. This financial market is very promising for international portfolio diversifycation. The GCC countries are dependent on oil to reach their economic growth. They have a very fast growth because of their large revenues from oil exports. According to EIA (Energy Information Administration), they possess the largest part of the world oil reserves. Understanding the impact of return and volatility spillovers across GCC markets is helpful for institutional and individual investors to engage in effective risk management and asset allocation.

Many empirical studies explore the phenomenon of transmission of volatility. It is important for financial market participants to understand the volatility transmission mechanisms over time and across these series in order to make optimal portfolio allocation decisions. Lanza, Manera, and Giovannini (2005) investigate heavy crude oil and product price dynamics. They present a comparison among ten price series of heavy crude oils and fourteen price series of petroleum products in two distinct areas Europe and Americas over the period 1994-2002. They use the error-correction model (ECM) specification to predict crude oil prices. Adrangi, Chatrath, Raffiee, and 
Ripple (2001) analyze the price dynamics of Alaska North Slope crude oil and L.A. diesel fuel prices. They employ the VAR methodology and bivariate GARCH model to show that there is a strong evidence of a unidirectional causal relationship between the two prices. Crude oil price volatility has been analyzed for organized spot, forward and futures markets for well over a decade.

Arouri, Jouini, and Nguyen (2012) study the transmission of volatility between the oil markets and the performance of European stock markets using the VAR-GARCH model. The results show that the transmission of volatility between oil prices and stock market returns is significant. In addition, the link between oil prices and the stock market is important for portfolio management and for calculating optimal coverage ratios for the oil markets.

Zhang and Wang (2014) analyze the return and volatility spillovers between China and world oil markets. The Chinese market is highly influenced by the import of oil. Moreover, it reached 305.9 million tons in 2011 and was ranked second in the world. The authors show that the return and volatility spillovers between China and world oil markets are bi-directional and asymmetric. Miller and Ratti (2009) examine the relationship between global crude oil prices and long-term international stock markets from over 1971-2008. They use a cointegrated vector error correction model with additional regressors. The authors found a long-term relationship between these series from six OECD (Organization for Economic Co-operation and Development) countries.

Sadorsky (2012) investigates the correlation and volatility spillovers between oil prices and stock prices of clean energy and technology companies. The author shows that oil price shocks have a negative impact because they adversely affect output and employment growth. Chang, McAleer, and Roengchai (2010) investigate the spillover effects in the returns on spot, forward and futures prices of four major benchmarks in the international oil market, namely West Texas Intermediate (USA), Brent (North Sea), Dubai/Oman (Middle East) and Tapis (Asia-Pacific), for the period 30 April 1997 to 10 November 2008. The authors show that the Chinese oil market is affected by world oil markets both in terms of return and volatility spillovers.
Korkmaz, Çevik, and Atukeren (2012) examine the return and volatility spillovers between the CIVETS countries (Colombia, Indonesia, Vietnam, Egypt, Turkey, and South Africa) by employing causality-in-mean and causality-in-variance tests. The empirical results indicate that the contemporaneous spillover effects are generally low. The structure of the causal relationships suggest the presence of intraregional and inter-regional return and volatility interdependence effects.

Malik and Ewing (2009) examine weekly returns from $1^{\text {st }}$ of January 1992 to $30^{\text {th }}$ of April 2008 between five different US sector indices and oil prices. They find evidence of significant transmission of shocks and volatility between oil prices and some of the examined market sectors. They use bivariate GARCH models to simultaneously estimate the mean and conditional variance between five different US sector indices and oil prices. The findings support the idea of cross-market hedging and sharing of common information by investors.

Malik and Hammoudeh (2007) examine the volatility and shock transmission mechanism among US equity, global crude oil market, and equity markets of Saudi Arabia, Kuwait, and Bahrain. The results show that, in all cases, Gulf equity markets receive volatility from the oil market. However, only the case of Saudi Arabia exhibits a significant volatility spillover from the Saudi market to the oil market.

\subsection{Specificities of Islamic indices}

The second strand in this review sub-section deals with three essentials: the baseline characteristics of Islamic finance, the extent to which Islamic financial intermediation is performing well in comparison to conventional financial intermediation (including their comparative performance during financial crises), and how the major Islamic equity indices are constructed to reflect market movements.

The early literature related to Sharī'ah (i.e., Islamic law) focuses on a set of prohibitions and permissible acts that must characterize business transactions in Islamic finance. The genesis and development of this Sharīah literature can be described through a three-step process. The first step consists in the early clarification of the general rules to all permissible and non-permissible business trans- 
actions as they stem from Qur'ān and Sunnah. The second step consists in the conceptualization of the Islamic rules governing business transactions. The last and most recent step consists of tailoring and implementing Islamic financial products.

All old treatises and recent conceptual and empirical studies ${ }^{(1)}$ in the aforementioned three-step process agree on the set of prohibitions (e.g., riba $\bar{a}$, gharar/maysir, unethical investments, and financial techniques) and the set of permissible (e.g., profitand-loss sharing and equity investments). Majdoub and Mansour (2014) claim that:

Islamic investing differs from the conventional one on many counts. Indeed, the institutional and individual investment decisions are restricted by a range of rules determined by scholars who are members of Sharīah Boards. Those scholars use Sharī ah in order to determine the general rules according to which the investment decisions are permissible. (p. 456)

Ariss (2010) argues that the prohibition of riba (usury or interest) is not exclusive to Islam. Indeed, it is common to religious texts in Judaism and Christianity $^{(2)}$. One of the reasons lying behind the prohibition of $r i b \bar{a}$ is that it is a gain earned without running risks. In addition, it disconnects the real and business activities and leads to injustice in business transactions. Gharar (uncertainties, complexities and/ or asymmetries) and maysir (gambling) are formally prohibited because they do not lead to a win-win game in financial contracting. The last prohibition is related to the blacklist (Nienhaus, 2011) of activities in which it is not permitted to invest, e.g., illicit activities violating human rights, armament, tobacco, adult entertainment, pork, and pornography ${ }^{(3)}$.

The set of permissible activities encompasses all actions that engender a win-win game, alleviate unfairness, and improve social welfare. The three major

(1) See Masood, Chichti, Mansour, and Amin (2009), Mansour, Ben Abdelhamid, Masood, \& Niazi (2010), Bedoui and Mansour (2015), and Mansour, Ben Jedidia, and Majdoub (2015) for a review of theoretical and empirical works in this regard.

(2) See Mansour and Jlassi (2014) and Mansour (2014) for an explanation of faith-based investments and coverage of the interplay between religions and finance.

(3) The set of prohibitions includes also some financial techniques such as short selling (because it can lead to an unlimited loss) and trading practices such as speculation. permissible activities are the profit-and-loss sharing (PLS) principle, lining real and financial activities, and combining individual and social interests. The heart of Islamic finance is the PLS principle. Indeed, Mansour, Ben Abdelhamid, and Heshmati (2015) claim that "recent theoretical and empirical studies show that the PLS-based financial contracts have not been successful due to several reasons, most importantly information asymmetry and its related costs when accessing debt financing" (p. 22).

A booming recent empirical literature studied the extent to which Islamic financial intermediation is performing well in comparison with conventional financial intermediation. The two most recognized reasons that are agreed upon and taken for granted as stylized facts are: Islamic financial intermediation stabilizes better the financial system and reduces transmission shocks across economies (Majdoub \& Mansour, 2014). There are supplementary empirical regularities and theoretical results documented in the Islamic finance literature. For example, capital and risk allocations are more efficient when Islamic equity-like products $^{(4)}$ are enforced after being tailored through the PLS principle. Many authors (e.g., Wilson, 1997) claim that equity-like financing modes are the closest form to the ideal mode of Islamic financing because it brings forth less harm to contracting parties, does not engender unjustly, and financiers cannot use the need of agents to exploit them by charging high financial fees. In addition, sharing profits and losses makes all parties better off relative to standard debt contracts.

Many empirical studies explore the extent to which Islamic financial intermediation is able to alleviate the transmission of shocks. Majdoub and Mansour (2014) use the MSCI Islamic equity index to study the correlation of volatility between indices of a sample of Islamic emerging equity markets and the US market through the investigation of dynamic conditional correlation. The results of the authors show that almost all pairs of countries exhibit a weak correlation of volatility. This fact can be interpreted

(4) A major challenge in Islamic financial engineering is embedding contractual provisions into equity-based contracts. Such provisions include: (i) pooling capital, expertise, and goodwill; (ii) PLS provisions; (iii) provisions related to handling negligence, termination and liquidation, and (iv) provisions on maturity. 
in terms of the insignificant transmission of shocks among the markets. Al-Khazali, Lean, and Samet (2014) study the performance of Islamic and conventional Dow Jones indices. They show that the domination of the conventional index over the Islamic index disappears during financial crises. The major implications inferred from the aforementioned studies and many others can be interpreted in terms of the benefits of prohibiting interest-bearing business transactions and restricting excessive leverage. Financial markets are less affected by volatility spillovers in such cases.

Various equity benchmarks are used in the Islamic finance industry, such as the FTSE Global Islamic Index Series, Dow Jones Islamic Market Index, and Morgan Stanley Global International (MSCI). All benchmarks are constructed using a very similar methodology that consists of a screening mechanism by excluding all securities that are non-compliant to Sharîah. Since this article uses the MSCI Islamic equity index, we will give particular attention to its methodology. The screening mechanism starts with screening the business activities of listed companies. According to Sharīa ah principles, companies are not allowed to invest, or derive more than $5 \%$ of their income, from activities related to alcohol, tobacco, conventional financial services, armament, gambling, cinemas, and adult entertainment.

Once the companies are filtered according to their business activities, they are screened financially. MSCI uses three ratios: (i) total debt to total assets; (ii) sum of a company's cash and interest-bearing securities to total assets; and (iii) sum of a company's accounts receivables and cash to total assets. A company is included in the MSCI Islamic equity index if all ratios do not exceed $33.33 \%$. For the new inclusions, a security can be a new constituent of the MSCI Islamic index if all the three ratios do not exceed 30\%. An additional purification is applied when a company derives a fraction of its total income from interest-bearing activities and/or from illicit/ unethical activities. A proportion of the cash dividend must be paid for charity purposes.

\section{Econometric Method}

We use the bivariate diagonal BEKK econometric method to assess volatility spillover effects. Developed by Engle and Kroner (1995), the diagonal
$\mathrm{BEKK}^{(5)}$ allows reducing the number of parameters of the covariance matrices to the diagonal. One of its advantages is that it allows the conditional covariance matrix to be finite positive. The general diagonal $\mathrm{BEKK}$ equation is given by:

$H_{t}=C^{\prime} C+A^{\prime}\left(\varepsilon_{t-1} \varepsilon_{t-1}^{\prime}\right) A+B^{\prime}\left(H_{t-1}\right) B$

where $H_{t}$ is the conditional variance-covariance matrix, $C$ is an upper triangular matrix of parameters, $\varepsilon_{t-1}$ in an $n \times 1$ disturbance vector, and $\mathrm{A}$ and $\mathrm{B}$ are $n \times n$ diagonal matrices of parameters. Considering that $\Omega$ is a $2 \times 2$ matrix defined as $C^{\prime} C$, a bivariate diagonal BEKK model can be written as follows:

$$
\begin{aligned}
\Omega & =\mathrm{C}^{\prime} \mathrm{C}=\left[\begin{array}{ll}
C_{11} & 0 \\
C_{12} & C_{22}
\end{array}\right]\left[\begin{array}{cc}
C_{11} & C_{12} \\
0 & C_{22}
\end{array}\right] \\
& =\left[\begin{array}{cc}
C_{11}^{2} & C_{12} C_{11} \\
C_{12} C_{11} & C_{12}^{2}+C_{22}^{2}
\end{array}\right]
\end{aligned}
$$

The variance-covariance matrix $H_{t}$ can be defined as:

$$
\begin{aligned}
H_{t} & =\left[\begin{array}{ll}
h_{11, t} & h_{12, t} \\
h_{21, t} & h_{22, t}
\end{array}\right]=\left[\begin{array}{ll}
\Omega_{11, t} & \Omega_{12, t} \\
\Omega_{21, t} & \Omega_{22, t}
\end{array}\right] \\
+ & {\left[\begin{array}{cc}
a_{11} & 0 \\
0 & a_{22}
\end{array}\right]\left(\left[\begin{array}{l}
u_{1, t-1} \\
u_{2, t-1}
\end{array}\right]\left[\begin{array}{l}
u_{1, t-1} \\
u_{2, t-1}
\end{array}\right]\right)\left[\begin{array}{cc}
a_{11} & 0 \\
0 & a_{22}
\end{array}\right] } \\
& +\left[\begin{array}{cc}
b_{11} & 0 \\
0 & b_{22}
\end{array}\right]\left[\begin{array}{ll}
h_{11, t-1} & h_{12, t-1} \\
h_{21, t-1} & h_{22, t-1}
\end{array}\right]\left[\begin{array}{cc}
b_{11} & 0 \\
0 & b_{22}
\end{array}\right]
\end{aligned}
$$

where $u$ is the error term.

Based on Eq. (3), it is easy to determine the three conditional variance and covariance equations:

$h_{11, t}=\Omega_{11, t}+a_{11}^{2} u_{1, t-1}^{2}+b_{11}^{2} h_{11, t-1}$

$h_{12, t}=\Omega_{12, t}+a_{11} a_{12} u_{1, t-1} u_{2, t-1}+$

$b_{11} b_{22} h_{12, t-1}$

$h_{22, t}=\Omega_{22, t}+a_{22}^{2} u_{2, t-1}^{2}+b_{22}^{2} h_{22, t-1}$

The estimation of the parameters of the threeequation system ${ }^{(6)}$ can be obtained when the assump-

(5) It is worth noting that we use the bivariate process developed by Engle and Kroner (1995). Other bivariate GARCH-type models are also considered and the minimum values of the Akaike Information Criterion (AIC) and Schwartz Bayesian Criterion (SBC) are used to compare between them. The results (not reported) are in favor of the Diagonal BEKK process to model the volatility dynamics of both Islamic/ Conventional indices and the oil price.

(6) It is noticeable that Eq. (5) will not be used in our regressions because we will use the diagonal bivariate BEKK. 
tion of conditional normality holds true. The maximization of the following log-likelihood function allows the determination of the estimates:

$$
L(\Theta)=-\frac{T n}{2}-\frac{1}{2} \sum\left(\log \left|H_{t}\right|+\varepsilon_{t} H_{t-1}^{-1} \varepsilon_{t}\right)
$$

where $T$ is the number of observations, $\Theta$ is the vector of parameters to be estimated, and $n$ is the number of periods.

Elements of matrix $\mathrm{A}$ are the coefficients of ARCH terms which show the effect of the shock in the market on conditional volatility. In addition, the elements of matrix $\mathrm{B}$ are the coefficients of the GARCH term which shows the effect of past conditional volatility on conditional volatility. It must, however, be noted that ARCH terms represent shortterm persistence volatility since the effect of shocks on conditional volatility is not expected to last long. However, the GARCH terms represent the long-term persistence volatility given the autoregressive nature of conditional volatility A and B.

\section{Hypothesis Development and Data Description}

\subsection{Hypothesis development}

Several empirical studies showed that the oil price has an impact on market indices. For instance, Arouri et al. (2012) show that the volatility transmission between the oil price and the market indices return is statistically significant. Sadorsky (2012) claims that there is an asymmetric effect in volatility transmission. Our main hypothesis can be stated as follows:

The volatility of the oil price influences differently the volatility of the Islamic equity indices than the conventional index.

\subsection{Data}

We use daily data spanning over the period starting from January 4, 2011 until January 4, 2015, which constitutes 1045 observations. Our dataset is made up of five countries, namely Jordan, Kuwait, Qatar, Saudi Arabia (KSA), and UAE (United Arab Emirates). We proxy for the return of stock market indices using the following formula:

$$
R_{t}=\ln \left(I_{t} / I_{t-1}\right)
$$

where $I_{t}$ and $I_{t-1}$ are the corresponding indices at $t$ and $t-1$.

Table 1 shows the five conventional and Islamic equity indices. Table 2 shows some descriptive statistics of the five conventional equity indices. It is clear that the corresponding means of Kuwait and Jordan are negative, which can be interpreted by the fact that these markets were declining during our sample period. The return volatility is proxied for using the standard deviation. The most volatile market is the UAE market. Table 3 shows the same descriptive statistics for the Islamic equity indices.

There is strong evidence that the return spreads of Islamic indices are higher than those of the conventional indices for the majority of series. This testifies to the ability of the Islamic finance industry to generate higher returns but, at the same time, engendering a higher risk. It is noticeable that the distributional properties of daily returns seem to be non-normal for both equity indices. Jarque-Bera test is significant at $1 \%$ in all cases. The null hypothesis of normality cannot be accepted.

\begin{tabular}{|c|c|c|}
\hline Country & Conventional benchmark & Islamic benchmark \\
\hline Saudi Arabia ${ }^{(7)}$ & KSA MSCI standard index & KSA MSCI Islamic index \\
\hline UAE & UAE MSCI standard index & UAE MSCI Islamic index \\
\hline Jordan & JOR MSCI standard index & JOR MSCI Islamic index \\
\hline Kuwait & KWT MSCI standard index & KWT MSCI Islamic index \\
\hline Qatar & QAT MSCI standard index & QAT MSCI Islamic index \\
\hline
\end{tabular}

Table (1) Variables: Islamic vs. conventional equity indices

(7) The conventional MSCI index for Saudi Arabia reflects the performance of the large and mid-cap segments of the domestic market. With 43 constituents, the index covers approximately $85 \%$ of the free float-adjusted market capitalization in Saudi Arabia. Regarding the Islamic MSCI index for Saudi Arabia, it was recently announced as an Islamic: MSCI Saudi Arabia Indices. It contains 19 constituents. 
Table (2) Descriptive statistics: conventional equity indices

\begin{tabular}{|l|c|c|c|c|c|c|c|}
\hline \multicolumn{1}{|c|}{ Country } & \multicolumn{1}{c|}{ Min } & \multicolumn{1}{c|}{ Max } & \multicolumn{1}{c|}{ Mean } & \multicolumn{1}{c|}{ Std. Dev. } & Skewness & Kurtosis & Jarque-Bera \\
\hline Saudi Arabia & -0.0187 & 0.0318 & $1.4 \mathrm{E}-05$ & 0.0030 & 0.3355 & 16.551 & $1916.0^{*}$ \\
\hline UAE & -0.0295 & 0.0347 & 0.00030 & 0.0052 & -0.3573 & 6.6837 & $601.06^{*}$ \\
\hline Jordan & -0.0233 & 0.0253 & -0.00016 & 0.0043 & -0.1560 & 5.9543 & $554.34^{*}$ \\
\hline Kuwait & -0.0234 & 0.0372 & -0.00012 & 0.0035 & 0.4039 & 15.88 & $1801.0^{*}$ \\
\hline Qatar & -0.0255 & 0.0383 & 0.00010 & 0.0040 & 0.5140 & 15.193 & $1656.7^{*}$ \\
\hline
\end{tabular}

"Statistical significance at $1 \%$.

Table (3) Descriptive statistics: Islamic equity indices

\begin{tabular}{|c|c|c|c|c|c|c|c|}
\hline Country & Min & Max & Mean & Std. Dev. & Skewness & Kurtosis & Jarque-Bera \\
\hline Saudi Arabia & $\begin{array}{c}-\mathbf{-} \\
0.0264\end{array}$ & 0.0483 & $-9.1 \mathrm{E}-06$ & 0.0040 & 1.0355 & 27.228 & $2843.1^{*}$ \\
\hline UAE & $\begin{array}{c}-- \\
0.0401\end{array}$ & 0.0576 & 0.0002 & 0.0071 & 0.2409 & 11.399 & $1248.4^{*}$ \\
\hline Jordan & $\begin{array}{c}- \\
0.0672\end{array}$ & 0.0416 & -0.0002 & 0.0070 & -0.3084 & 13.076 & $1455.9^{*}$ \\
\hline Kuwait & $\begin{array}{c}-- \\
0.0288\end{array}$ & 0.0438 & -0.0001 & 0.0045 & 0.2695 & 11.971 & $1318.2^{*}$ \\
\hline Qatar & $\begin{array}{c}-- \\
0.0325\end{array}$ & 0.0531 & 0.0001 & 0.0047 & 1.2296 & 22.698 & $2002.6^{*}$ \\
\hline
\end{tabular}

"Statistical significance at $1 \%$.

Figure 1 shows the daily conventional indices for the five countries over the sample period. Although the index series have similar trends, KSA and Qatar exhibit very close trends. In addition, Kuwait and Jordan exhibit similar trends of their corresponding series. However, the UAE exhibits a different increasing behavior that appears to persist clearly during the last quarter of 2014.

The linkage between Brent and conventional indices plays an important role particularly for portfolio holders because oil prices affect share prices. Also, since the price of a share is equal to its discounted future cash flow, rising oil prices can increase the interest rate to limit inflationary pressure. Figure 2 shows the daily index returns of the conventional indices and Brent in log-differences and shows less volatility except for 2015 which exhibits a higher volatility. This can be explained by the fall in the oil price over the last years. Figures 3 and 4 show the fluctuations of the Islamic indices and the daily index returns for the five countries and Brent. Whilst UAE and Qatar markets exhibit an upward trend, the remaining series show a downward trend.
The plots of the daily stock market indices and returns for the conventional and Islamic markets display volatility clustering and leverage effects. As explained by Mandelbrot (1963), volatility clustering means that "large changes tend to be followed by large changes, of either sign, and small changes tend to be followed by small changes" (p. 418). This economic phenomenon can be explained by the uninterrupted effect of external demand and/or technological shocks. Accordingly, ARCH models are applicable in this case. Whilst Engle (1982) explains the volatility clustering in terms of the regularity of return time series, Bollerslev (1986) explains it in terms of the heteroskedasticity of the return sequence residuals. The leverage effect can be explained through the non-uniform impact of information on volatility. Black (1976) shows that positive and negative information (i.e., good and bad news) have different impacts on volatility. In other words, the current return and future volatility are negatively correlated. 

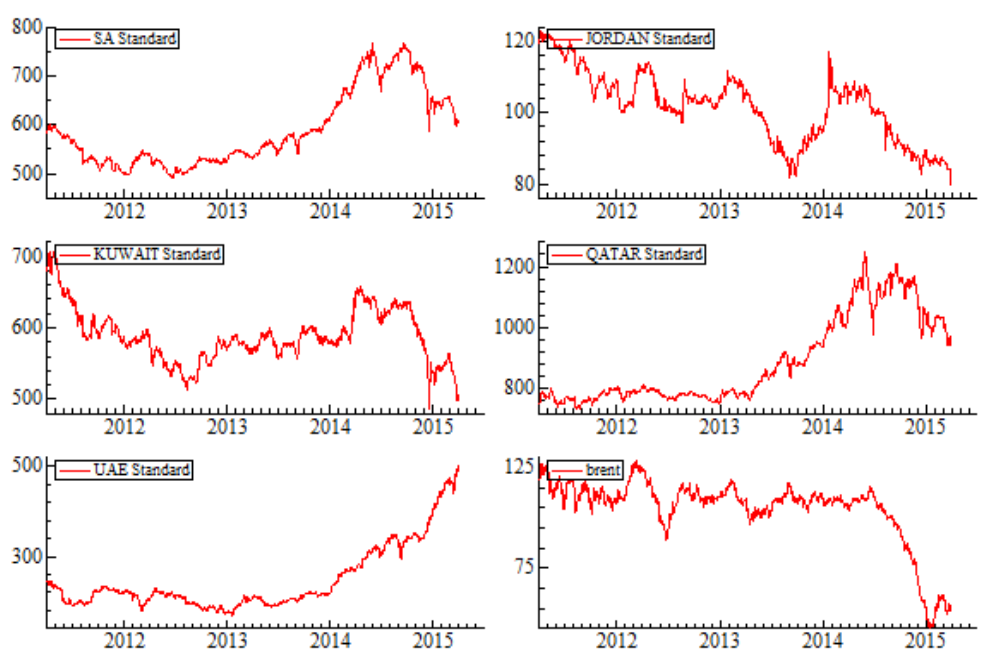

Figure (1) Conventional indexes vs. Brent (2011-2015)
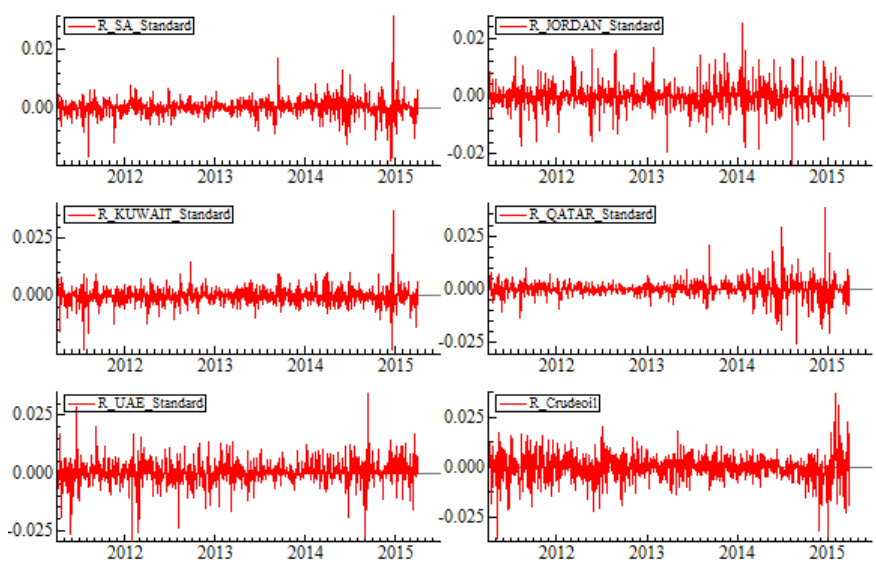

Figure (2) Daily returns: conventional indices vs. Brent (2011-2015)
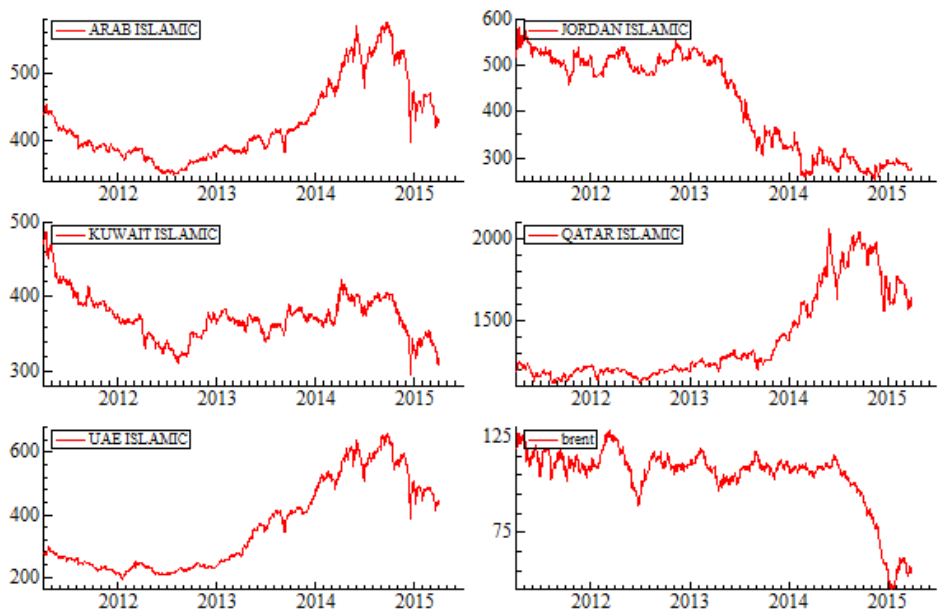

Figure (3) Islamic indices vs. Brent (2011-2015) 

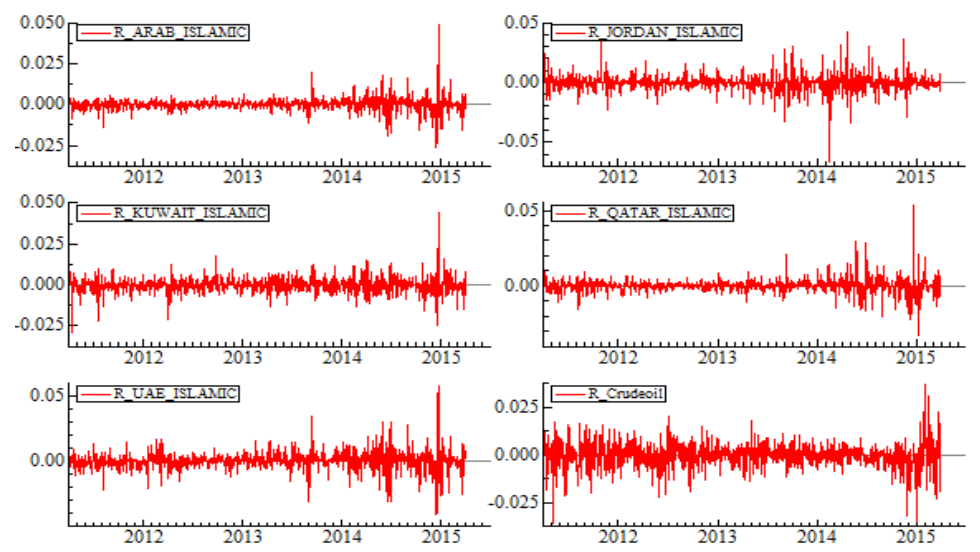

Figure (4) Daily returns: Islamic indices vs. Brent (2011-2015)

Table 4 shows the matrix correlations of conventional equity returns, alongside the correlation with Brent. It is clear that all indices exhibit a significant and positive return. The lowest correlation is between Jordan and UAE. Regarding the correlation with Brent, the Saudi market shows the highest value equal to 0.0977 . This means that the business activities of the companies included in the conventional equity index depend on the oil price.

We notice that the correlation between the oil price and both Jordanian and UAE conventional index returns are negative, which can be interpreted in terms of worsening impacts of oil price increase. Indeed, Nandha and Faff (2008) claim that the increase of the oil price has a negative impact on all sectors. However, the correlation between the Islamic index for Jordan with Brent is positive as shown in Table 5. We can argue that the Islamic index discards all firms having an excessive interest burden, which improves the profitability of companies included in the MSCI Islamic equity index. This is a logical explanation for the Jordanian market because Jordan is not an oil-producing economy. For the case of UAE, the correlation is close to zero and shows low dependence on oil price, which can be explained by the difference in its economic structure compared to others gulf countries.

Table (4) Matrix correlations of returns: conventional indexes

\begin{tabular}{|l|c|c|c|c|c|c|}
\hline \multicolumn{1}{|c|}{ Countries } & KSA & Jordan & Kuwait & Qatar & UAE & Crude oil \\
\hline KSA & 1.0000 & 0.1896 & 0.6797 & 0.7202 & 0.0335 & 0.0977 \\
\hline Jordan & & 1.0000 & 0.1243 & 0.1479 & 0.0120 & -0.0029 \\
\hline Kuwait & & & 1.0000 & 0.2911 & 0.0227 & 0.0406 \\
\hline Qatar & & & & 1.0000 & 0.0564 & 0.0782 \\
\hline UAE & & & & & 1.0000 & -0.0376 \\
\hline Crude oil & & & & & & 1.0000 \\
\hline
\end{tabular}

Table (5) Matrix correlations of returns: Islamic indexes

\begin{tabular}{|l|c|c|c|c|c|c|}
\hline \multicolumn{1}{|c|}{ Country } & KSA & Jordan & Kuwait & Qatar & UAE & Crude oil \\
\hline KSA & 1.0000 & 0.0682 & 0.0620 & 0.7671 & 0.8442 & 0.1093 \\
\hline Jordan & & 1.0000 & 0.0092 & 0.0923 & 0.0769 & 0.0250 \\
\hline Kuwait & & & 1.0000 & 0.2614 & 0.3524 & 0.0197 \\
\hline Qatar & & & & 1.0000 & 0.5369 & 0.1122 \\
\hline UAE & & & & & 1.0000 & 0.0755 \\
\hline Crude oil & & & & & & 1.0000 \\
\hline
\end{tabular}


Figure 5 shows five panels indicating the time varying conditional correlations for the five conventional and Islamic indices with the crude oil price. There is clearly a decline in the dynamic correlation. For example, the first panel (Figure 5(a)) shows that the correlation did not exceed 0.4 for the Jordan Islamic index, whilst it exceeded 0.6 for the conventional
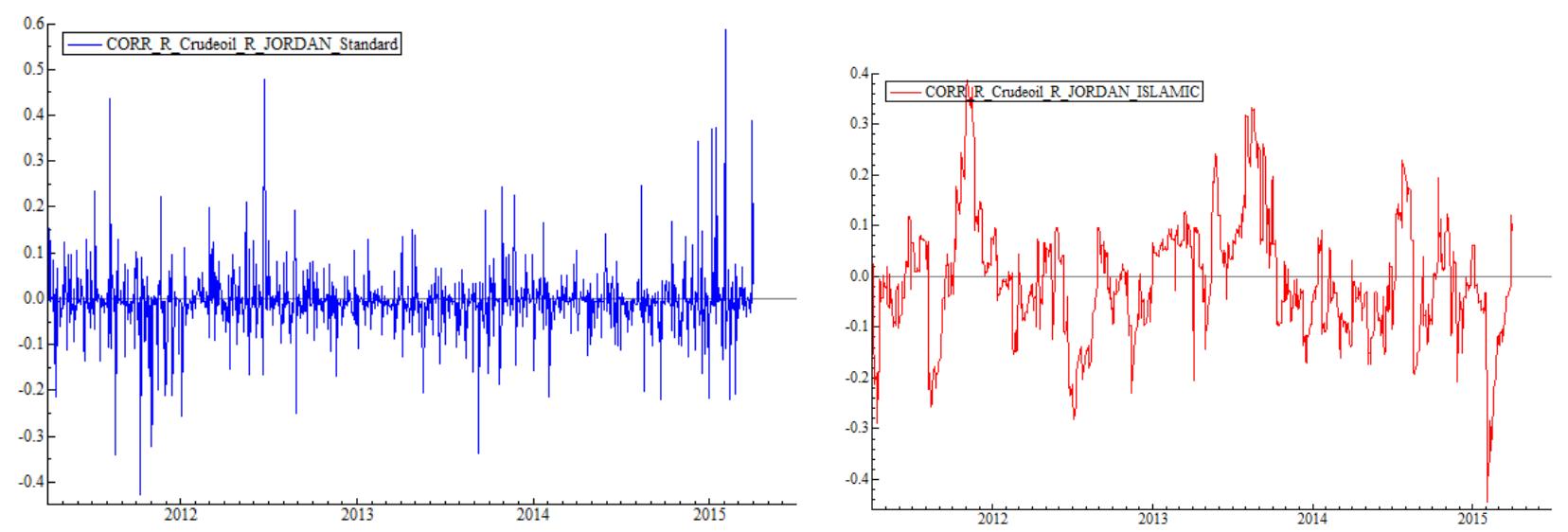

Figure 5(a) Time-varying conditional correlations for Jordan: Conventional vs. Islamic
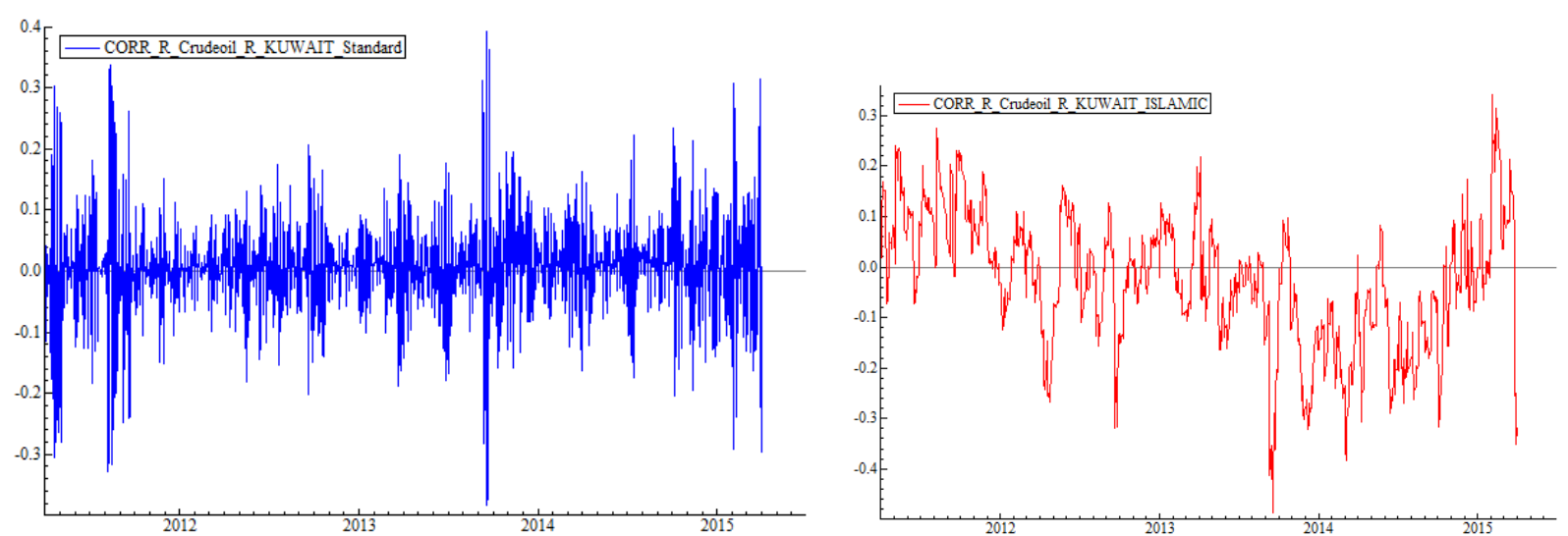

Figure 5(b) Time-varying conditional correlations for Kuwait: Conventional vs. Islamic 

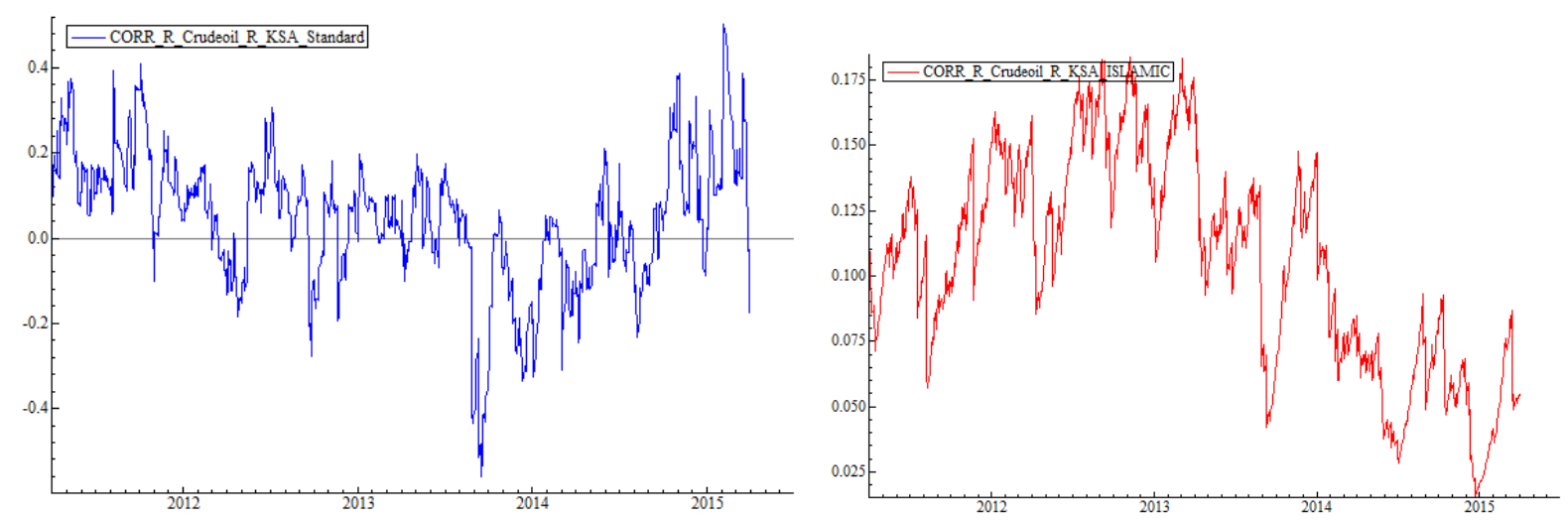

Figure 5(c) Time-varying conditional correlations for KSA: Conventional vs. Islamic
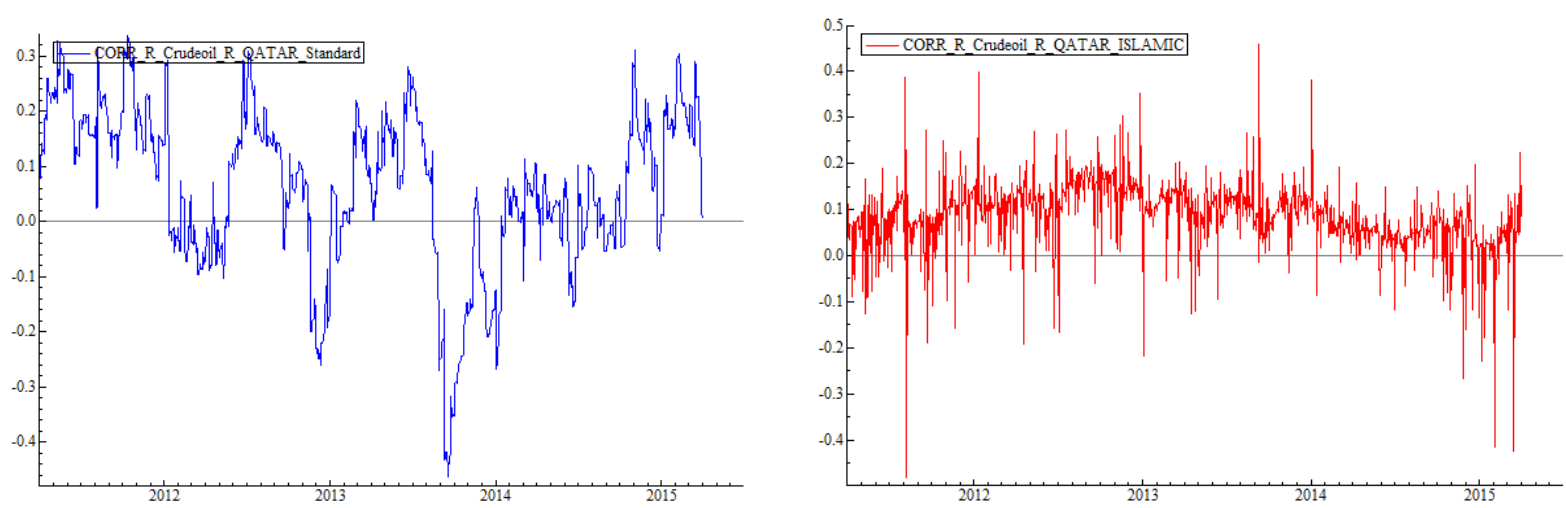

Figure 5(d) Time-varying conditional correlations for Qatar: Conventional vs. Islamic
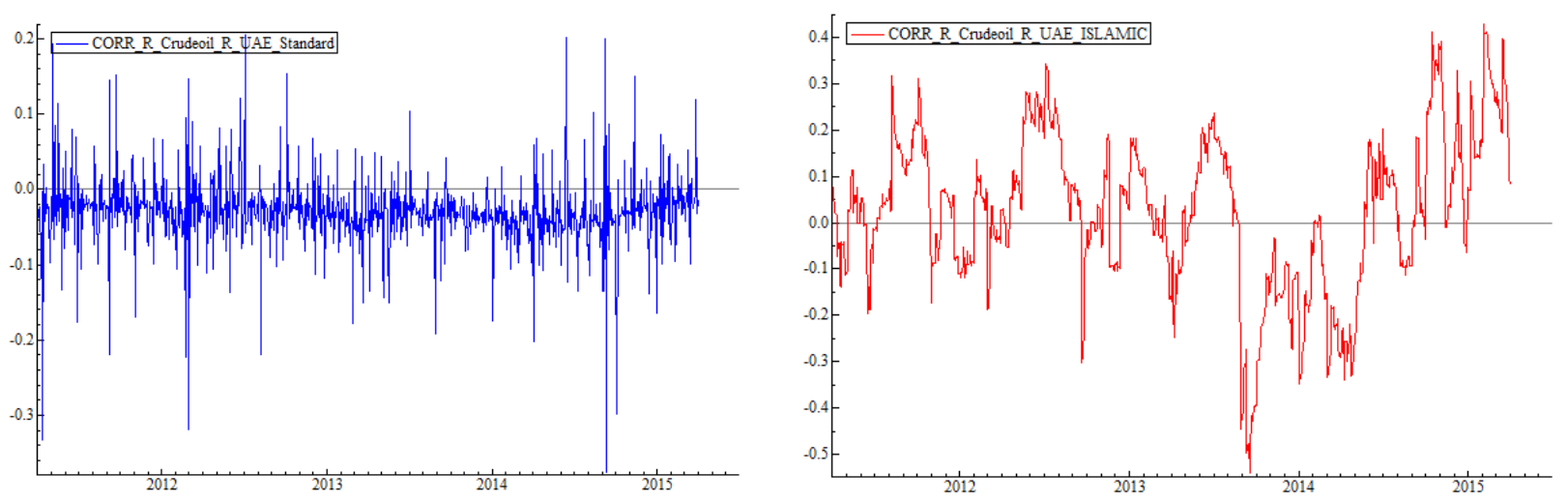

Figure 5(e) Time-varying conditional correlations for UAE: Conventional vs. Islamic 
A supplementary portfolio implication can be inferred from Figure 5 in terms of the reduction of the dynamic correlation between the index and the crude oil price. Indeed, Philips, Walker, and Kinniry (2012) claim that:

It's common to hear of the value of diversification during uncertain or volatile markets. Indeed, a broadly diversified, balanced portfolio is unlikely to perform as poorly as a portfolio focused entirely on stocks, if stocks enter a bear market or experience seemingly abnormal volatility. (p. 1)

This perception disappointed market participants during the 2008 global financial crisis casting a doubt on the benefits of diversification. According to Philips et al. (2012, p.1), real and financial assets exhibited over 2009-2012 high correlations with U.S. equities ranging from 0.6 (for commodities) to 0.93 (for developed international markets). The authors confirm that only U.S. Treasury bonds have proven to be a true diversifier, correlating at -0.3 to U.S. equities. Since our results show a sheer decline in the dynamic correlations for all five countries, we can argue that not only the crude oil price is weakly correlated over time with the Islamic equity indices, but also investing in these equity markets contributes to better diversification. Indeed, funds' managers can benefit from Islamic financial principles and local/ international diversification to build portfolios and design effective hedging while benefiting from the weak dynamic correlations between Islamic equity markets and crude oil prices.

\section{Interpretation of Results and Policy Implications}

The conditional variance-covariance equations measure the volatility of the oil price among the five countries since most of the coefficients in Tables 6 and 7 are positive. The conditional variance and covariances determined by the diagonal BEKK specification are given by the equations (A1)-(A20) in the appendix for the conventional and Islamic markets.

Table (6) Estimated coefficients for conditional variance-covariance equations: conventional indices

\begin{tabular}{|c|c|c|c|c|c|c|}
\hline & $c_{11}$ & $c_{22}$ & $a_{11}$ & $a_{22}$ & $b_{11}$ & $b_{22}$ \\
\hline KSA & $\begin{array}{l}0.0006^{\mathrm{a}} \\
(4.640)\end{array}$ & $\begin{array}{l}0.0004^{b} \\
(2.186)\end{array}$ & $\begin{array}{l}0.2927^{\mathrm{a}} \\
(8.219)\end{array}$ & $\begin{array}{l}0.2129^{\mathrm{a}} \\
(9.644)\end{array}$ & $\begin{array}{l}0.9327^{\mathrm{a}} \\
(55.17)\end{array}$ & $\begin{array}{l}0.9763^{\mathrm{a}} \\
(223.6)\end{array}$ \\
\hline KUWAIT & $\begin{array}{c}0.000358 \\
(0.5050) \\
\end{array}$ & $\begin{array}{c}-0.232466^{\mathrm{a}} \\
(-6.289)\end{array}$ & $\begin{array}{l}0.1982^{\mathrm{a}} \\
(2.796) \\
\end{array}$ & $\begin{array}{c}0.029176 \\
(1.339) \\
\end{array}$ & $\begin{array}{c}0.011385^{\mathrm{a}} \\
(4.365) \\
\end{array}$ & $\begin{array}{c}0.357433^{\mathrm{a}} \\
(5.402) \\
\end{array}$ \\
\hline JORDAN & $\begin{array}{c}0.000325 \\
(0.4382)\end{array}$ & $\begin{array}{c}-0.220647^{\mathrm{a}} \\
(-6.422)\end{array}$ & $\begin{array}{l}0.3154^{\mathrm{a}} \\
(2.873)\end{array}$ & $\begin{array}{c}0.028088 \\
(1.265)\end{array}$ & $\begin{array}{c}0.010883^{\mathrm{a}} \\
(3.528)\end{array}$ & $\begin{array}{c}0.323701^{\mathrm{a}} \\
(4.564)\end{array}$ \\
\hline QATAR & $\begin{array}{l}-0.000022 \\
(-0.02923)\end{array}$ & $\begin{array}{c}-0.156886 \\
(-1.314)\end{array}$ & $\begin{array}{l}02024^{\mathrm{a}} \\
(2.736) \\
\end{array}$ & $\begin{array}{c}0.035858 \\
(1.609) \\
\end{array}$ & $\begin{array}{c}0.012513^{\mathrm{a}} \\
(6.754) \\
\end{array}$ & $\begin{array}{c}0.448231^{\mathrm{a}} \\
(5.455) \\
\end{array}$ \\
\hline UAE & $\begin{array}{c}0.000191 \\
(0.2642) \\
\end{array}$ & $\begin{array}{c}-0.254967^{\mathrm{a}} \\
(-7.140)\end{array}$ & $\begin{array}{l}0.2167^{\mathrm{a}} \\
(2.809)\end{array}$ & $\begin{array}{c}0.031483 \\
(1.452)\end{array}$ & $\begin{array}{c}0.012019^{\mathrm{a}} \\
(4.549)\end{array}$ & $\begin{array}{c}0.356359^{\mathrm{a}} \\
(6.082) \\
\end{array}$ \\
\hline
\end{tabular}

Notes to table: ${ }^{\mathrm{a}},{ }^{\mathrm{b}}$ and ${ }^{\mathrm{c}}$ imply significance at the $1 \%, 5 \%$, and $10 \%$ levels, respectively. The values in brackets are $t$-statics. 
The ARCH effects (own-volatility) are positive and significant for all countries. The spillover effect is higher for Jordan $(0.0995)$ and KSA $(0.0856)$ than for the UAE (0.0470), Qatar (0.0410), and Kuwait (0.0393), referring respectively to equations A9, A1, A17, A13, and A5. These estimated parameters reflect the volatility persistence for each market in terms of its own past errors. Regarding the GARCH effects of the oil price, it is clear that all estimated coefficients are positive and significant except for Kuwait (-0.2943). The spillover effect is higher for Jordan (0.1043), and Kuwait (0.0866) than for the UAE (0.0567), Qatar (0.0464) and KSA (0.0453) referring respectively to equations $\mathrm{A} 2, \mathrm{~A} 10, \mathrm{~A} 6, \mathrm{~A} 18$, and A14. These estimates show that the Jordanian market reflects the highest volatility persistence for the conventional equity index as well as for the oil price. We can infer that the Jordanian market is the least vulnerable to outside oil shocks. UAE can also be interpreted in the same manner.

The GARCH effect is reflected by the lagged ownvolatility persistence. As for the conventional equity indices, we can notice that the GARCH effects are higher for Kuwait (0.9592) and Qatar (0.9572) than for the UAE (0.9514), KSA (0.8699), and Jordan (0.0000). This suggests that volatility persistence of Kuwait's conventional equity index is driven more by the domestic market. In contrast, the volatility persistence of the Jordanian market depends highly on outside markets (i.e., it derives more of its volatility persistence from outside than the local market). Regarding the GARCH effects of the oil price, it is positive and significant except for Kuwait and UAE. The estimates are higher for Qatar (0.9533) and KSA (0.9531) than for Kuwait (0.7906), Jordan (0.6520) and UAE (0.0268). The Qatari market derives more of its volatility persistence of the oil price from within the domestic market, whilst the UAE market derives more of its oil price's volatility persistence from outside the domestic market. In other words, an external high shock can engender persistence in the oil price's volatility for UAE. The opposite is true in the case of Qatar.

Table 7 shows the estimation results regarding the Islamic equity indices for the five countries, alongside the oil price. The corresponding ARCH effects are positive and significant for all countries. The spillover effect is higher for Qatar (0.1162) than for Kuwait (0.0460), UAE (0.0433), Jordan (0.04223) and KSA (0.0000). Regarding the ARCH effects of the oil price, it turns out that it is positive for UAE and Kuwait only. The spillover effect is higher for KSA (0.0857) and Kuwait (0.0780) than for Qatar (0.0679), Jordan (0.0651), and UAE (0.0568).

We can conclude that, in comparison with the estimates of the conventional indices as shown in Table 6, Jordan became fourth-ranked (when using the Islamic version of MSCI) and was ranked first in its corresponding ARCH effect related to its conventional equity index. A very similar result arises for the ARCH effect corresponding to the oil price. In addition, KSA became fifth-ranked (when using the Islamic version of MSCI) and was ranked second in its corresponding $\mathrm{ARCH}$ effect related to its equity index. Regarding the ARCH effects related to oil price, KSA was ranked fifth and became first-ranked after using the Islamic index.

These results can be interpreted by the following arguments. The conventional equity index seems to generate results according to which the estimates results show that Jordan is the least vulnerable to shocks, whilst KSA is the most vulnerable. After using the Islamic MSCI equity index, the results changed because KSA became the least vulnerable, followed by Kuwait and Qatar. This fact seems to be more logical. Indeed, the Islamic financial intermediation mode alleviates the shock transmission. The KSA market seems to transmit a lower volatility to oil markets. 
Table (7) Estimated coefficients for conditional variance-covariance equations: Islamic indices

\begin{tabular}{|l|l|l|l|l|l|l|}
\hline & \multicolumn{1}{|c|}{$\boldsymbol{c}_{\mathbf{1 1}}$} & \multicolumn{1}{c|}{$\boldsymbol{c}_{\mathbf{2 2}}$} & \multicolumn{1}{c|}{$\boldsymbol{a}_{\mathbf{1 1}}$} & \multicolumn{1}{c|}{$\boldsymbol{a}_{\mathbf{2 2}}$} & \multicolumn{1}{c|}{$\boldsymbol{b}_{\mathbf{1 1}}$} & \multicolumn{1}{c|}{$\boldsymbol{b}_{\mathbf{2 2}}$} \\
\hline KSA & $\begin{array}{l}-0.0001 \\
(-0.1699)\end{array}$ & $\begin{array}{l}-0.210218^{\mathrm{a}} \\
(-6.072)\end{array}$ & $\begin{array}{l}0.000353^{\mathrm{a}} \\
(2.798)\end{array}$ & $\begin{array}{l}0.028750 \\
(1.305)\end{array}$ & $\begin{array}{l}0.012113^{\mathrm{a}} \\
(4.424)\end{array}$ & $\begin{array}{l}0.333984^{\mathrm{a}} \\
(5.720)\end{array}$ \\
\hline KUWAIT & $\begin{array}{l}0.000358 \\
(0.5050)\end{array}$ & $\begin{array}{l}-0.232466^{\mathrm{a}} \\
(-6.289)\end{array}$ & $\begin{array}{l}0.000354^{\mathrm{a}} \\
(2.796)\end{array}$ & $\begin{array}{l}0.029176 \\
(1.339)\end{array}$ & $\begin{array}{l}0.011385^{\mathrm{a}} \\
(4.365)\end{array}$ & $\begin{array}{l}0.357433^{\mathrm{a}} \\
(5.402)\end{array}$ \\
\hline JORDAN & $\begin{array}{l}0.000325 \\
(0.4382)\end{array}$ & $\begin{array}{l}-0.220647^{\mathrm{a}} \\
(-6.422)\end{array}$ & $\begin{array}{l}0.000362^{\mathrm{a}} \\
(2.873)\end{array}$ & $\begin{array}{l}0.028088 \\
(1.265)\end{array}$ & $\begin{array}{l}0.010883^{\mathrm{a}} \\
(3.528)\end{array}$ & $\begin{array}{l}0.323701^{\mathrm{a}} \\
(4.564)\end{array}$ \\
\hline QATAR & $\begin{array}{l}0.000022 \\
(-0.02923)\end{array}$ & $\begin{array}{l}-0.156886 \\
(-1.314)\end{array}$ & $\begin{array}{l}0.000349^{\mathrm{a}} \\
(2.736)\end{array}$ & $\begin{array}{l}0.035858 \\
(1.609)\end{array}$ & $\begin{array}{l}0.012513^{\mathrm{a}} \\
(6.754)\end{array}$ & $\begin{array}{l}0.448231^{\mathrm{a}} \\
(5.455)\end{array}$ \\
\hline UAE & $\begin{array}{l}0.000191 \\
(0.2642)\end{array}$ & $\begin{array}{l}-0.254967^{\mathrm{a}} \\
(-7.140)\end{array}$ & $\begin{array}{l}0.000356^{\mathrm{a}} \\
(2.809)\end{array}$ & $\begin{array}{l}0.031483 \\
(1.452)\end{array}$ & $\begin{array}{l}0.012019^{\mathrm{a}} \\
(4.549)\end{array}$ & $\begin{array}{l}0.356359^{\mathrm{a}} \\
(6.082)\end{array}$ \\
\hline
\end{tabular}

Notes to table: ${ }^{\mathrm{a}},{ }^{\mathrm{D}}$ and ${ }^{\mathrm{c}}$ imply significance at the $1 \%, 5 \%$, and $10 \%$ levels, respectively. The values in brackets are $t$-statics.

Table 7 shows that the GARCH effects are higher for Jordan (0.9574) and UAE (0.9547) than for Kuwait (0.9527), KSA (0.4951), and Qatar (0.0000). This suggests that the volatility's persistence of the Jordanian Islamic equity index is driven by the domestic market. It does not depend on outside markets, which means that it does not derive more of its volatility persistence from outside the domestic market. This is a major advantage of the Islamic index because the Jordanian market became less vulnerable, which means that the persistence of its volatility to oil shocks is reduced.

Regarding the GARCH effects of the oil price, it is positive and significant except for Qatar. The estimates are higher for Qatar (0.9319) and UAE (0.9273) than for KSA (0.9133), Jordan (0.9131), and Kuwait (0.8480). We can conclude that, after using the Islamic index, the UAE market derives more of its volatility persistence from within the domestic market. Jordan's volatility persistence did not change after using the Islamic index, which is logical since it is not an oil-producing country.

On balance, our results suggest that the use of the MSCI Islamic equity index reduces volatility persistence over time. Although the countries contained in our sample face heterogeneous risk-return profiles and different levels of vulnerability to outside oil shocks, the vulnerability of the market to oil prices becomes reduced. Our stated hypothesis is, therefore, confirmed because the volatility of the oil price influenced differently the volatility of the Islamic equity indices for the five countries in our sample.

There are some policy implications that can be derived from our results. Firstly, the link between the Islamic equity index is crucial for investors and corporate decision makers because the volatility of oil prices impacts on the trading prices of stocks. Increasing prices would lead to an increase in the opportunity cost, which may impair corporate profitability. Secondly, our results can be useful for hedging effectiveness and portfolio diversification. Indeed, the reduction in volatility persistence can be used as a clue by portfolio managers to diversify the risk exposure of their international portfolios. Thirdly, the Islamic financial intermediation mode seems to alleviate the transmission of oil shocks. This is clear because we found that the Saudi market became less vulnerable to oil shocks after we used the MSCI Islamic equity index. The reduction in the volatility spillover is attributed to the specificities of the business and financial screening mechanisms used to include companies. Although KSA is the largest oil-producing country in the world, it seems that the Saudi domestic market is safer when Islamic financial principles are used. 


\section{Conclusion}

This article studies an important issue in the empirical financial markets literature, namely the volatility spillover between equity markets and the oil price. Recent empirical studies start from the importance of this topic and conducted investigations showing that there is a volatility transmission relationship. For instance, Zhang and Wang (2014) study the return and volatility spillovers between China and worldwide oil markets and show that such spillovers are bidirectional and asymmetric.

The purpose of this article does not focus on the study of the volatility spillover that might exist between the conventional equity market index and the oil price. In contrast, the point is to study volatility spillover between the Islamic equity market index and the oil price seeing that the latter is deemed to reflect Islamic financial principles. We use the MSCI Islamic equity index that contains stocks that are compliant with the Sharíah, i.e., do not invest in illicit/unethical sectors and do not have excessive leverage.

\section{References}

Adrangi, B., Chatrath, A., Raffiee, K., \& Ripple, R. D. (2001). Alaska North Slope crude oil price and the behavior of diesel prices in California. Energy Economics, 23(1), 29-42.

Ariss, R. T. (2010). Competitive conditions in Islamic and conventional banking: A global perspective. Review of Financial Economics, 19(3), 101-108.

Arouri, M., Jouini, J., \& Nguyen, D. K. (2012). On the impacts of oil price fluctuations on European equity markets: Volatility spillover and hedging effectiveness. Energy Economics, 34(2), 611-617.

Bedoui, H. E., \& Mansour, W. (2015). Performance and Maqasid al-Shari'ah's pentagon-shaped ethical measurement. Science and Engineering Ethics, 21(3), 555576.

Black, F. (1976). Studies of stock market volatility changes. In American Statistical Association, Proceeding of the 1976 Meeting of the Business and Economic Statistics Section (pp. 177-181). Washington DC: American Statistical Association.

Bollerslev, T. (1986). Generalized autoregressive conditional heteroskedasticity. Journal of Econometrics, 31(3), 307-327.
Using the bivariate BEKK as an econometric method, our results reveal several interesting facts. Indeed, we mainly show that, when using the MSCI Islamic equity index, volatility spillover is reduced and volatility persistence is alleviated. The case of Saudi Arabia is the most salient because our results show that this country becomes less vulnerable to oil shocks. This is caused by the features of the Islamic financial principles that alleviate the transmission of shocks (particularly in situations of financial crises), stabilize the financial markets, and enhance risk and capital allocation. Our results can be beneficial to policymakers and portfolio managers in terms of hedging effectiveness and international diversification.

Our article can be extended in various ways since many empirical and conceptual issues remain unanswered. For example, the contagion effect can be studied in the case of oil shocks. In addition, the use of intra-daily data can reveal interesting empirical implications. Finally, exploring the study of return spillover can also add valuable findings.

Chang, C.-L., McAleer, M. J., \& Roengchai, T. (2010). Analyzing and forecasting volatility spillovers, asymmetries and hedging in major oil markets. Energy Economics, 32(6), 1445-1455.

Engle, R. (1982). Autoregressive conditional heteroskedasticity with estimates of the variance of United Kingdom inflation. Econometrica, 50(4), 987-1007.

Engle, R., \& Kroner, K. F. (1995). Multivariate Simultaneous Generalized ARCH. Econometric Theory, 11(1), 122-150.

Islamic Financial Services Board (IFSB). (2017). Islamic financial services industry stability report. Kuala Lumpur, Malaysia: Author. Retrieved from: www.ifsb. org/docs/IFSB \%20IFSI\%20Stability\%20Report\%2020 17.pdf

al-Khazali, O., Lean, H. H., \& Samet, A. (2014). Do Islamic stock indexes outperform conventional stock indexes? A stochastic dominance approach. PacificBasin Finance Journal, 28(C), 29-46.

Korkmaz, T., Çevik, E., \& Atukeren, E. (2012). Return and volatility spillovers among CIVETS stock markets. Emerging Markets Review, 13(2), 230-252. 
Lanza, A., Manera, M., \& Giovannini, M. (2005). Modeling and forecasting cointegrated relationships among heavy oil and product prices. Energy Economics, 27(6), 831-848.

Majdoub, J., \& Mansour, W. (2014). Islamic equity market integration and volatility spillover between emerging and US stock markets. North-American Journal of Economics and Finance, 29(3), 452-470.

Malik, F., \& Hammoudeh, S. (2007). Shock and volatility transmission in the oil, US and Gulf equity markets. International Review of Economics \& Finance, 16(3), 357-368.

Malik, F., \& Ewing, B. (2009). Volatility transmission between oil prices and equity sector returns. International Review of Financial Analysis, 18(3), 95-100.

Mandelbrot, B. (1963). The variation of certain speculative prices. Journal of Business, 36(4), 394-419.

Mansour, W., Ben Jedidia, K., \& Majdoub, J. (2015). How ethical is Islamic banking in the light of Islamic law? The Journal of Religious Ethics, 43(1), 51-77.

Mansour, W. (2014). Editorial. Special issue on Religions and Finance. International Journal of Behavioural Accounting and Finance, 4(3), 187-190.

Mansour, W., \& Jlassi, M. (2014). The effect of religion on financial and investing decisions. In H. Kent Baker, \& Victor Ricciardi (Eds.), Investor Behavior - The Psychology of Financial Planning and Investing (pp. 135-151). New York: Wiley-Blackwell.

Mansour, W., Ben Abdelhamid, M., \& Heshmati, A. (2015). Recursive profit-and-loss sharing. Journal of Risk, 17(6), 21-50.
Mansour, W., Ben Abdelhamid, M., Masood, O., \& Niazi, G. S. K. (2010). Islamic banking and the customers' preferences: the case of the UK. Qualitative Research in Financial Markets, 2(3), 185-199.

Masood, O., Chichti, J. E., Mansour, W., \& Amin, Q. A. (2009). Role of Islamic mortgage in UK. International Journal of Monetary Economics and Finance, 2(3/4), 366-383.

Miller, J. I., \& Ratti, R. A. (2009). Crude oil and stock markets: Stability, instability, and bubbles. Energy Economics, 31(4), 559-568.

Nandha, M., \& Faff, R. (2007). Does oil move equity prices? A global view. Energy Economics, 30(3), 986997.

Nienhaus, V. (2011). Islamic finance ethics and Shari'ah law in the aftermath of the crisis: Concept and practice of Shari'ah-compliant finance. Ethical Perspectives, 18(4), 591-623.

Philips, C., Walker, D., \& Kinniry, F. (2012). Dynamic correlations: the implications for portfolio construction. Retrieved from: http://www.vanguard.com/pdf/s130.pdf

Sadorsky, P. (2012). Correlations and volatility spillovers between oil prices and the stock prices of clean energy and technology companies. Energy Economics, 34(1), 248-255.

Wilson, R. (1997). Islamic finance and ethical investment. International Journal of Social Economics, 24(11), 1325-1342.

Zhang, B., \& Wang, P. (2014). Return and volatility spillovers between china and world oil markets Economic Modelling, 42(C), 413-420. 


\section{Appendix}

Brent (1) vs. KSA (2): Conventional

$h_{11, t}=0.0006+0.0856 u_{1, t-1}^{2}+0.8699 h_{11, t-1}$
$h_{22, t}=0.0004+0.0453 u_{2, t-1}^{2}+0.9531 h_{22, t-1}$

Brent (1) vs. KSA (2): Islamic

$h_{11, t}=0.0046+0.0000 u_{1, t-1}^{2}+0.4951 h_{11, t-1}$

$h_{22, t}=0.0002+0.0857 u_{2, t-1}^{2}+0.9133 h_{22, t-1}$

Brent (1) vs. KWT (2): Conventional

$h_{11, t}=0.0003+0.0393 u_{1, t-1}^{2}+0.9592 h_{11, t-1}$
$h_{22, t}=0.0010+0.0866 u_{2, t-1}^{2}+0.7906 h_{22, t-1}$

Brent (1) vs. KWT (2): Islamic

$h_{11, t}=0.0003+0.0460 u_{1, t-1}^{2}+0.9527 h_{11, t-1}$

$h_{22, t}=0.0011+0.0780 u_{2, t-1}^{2}+0.8480 h_{22, t-1}$

Brent (1) vs. JOR (2): Conventional

$h_{11, t}=0.0061+0.0995 u_{1, t-1}^{2}+0.0000 h_{11, t-1}$

$h_{22, t}=0.0020+0.1043 u_{2, t-1}^{2}+0.6520 h_{22, t-1}$

Brent (1) vs. JOR (2): Islamic

$h_{11, t}=0.0003+0.04223 u_{1, t-1}^{2}+0.9574 h_{11, t-1}$

$h_{22, t}=0.0011+0.0651 u_{2, t-1}^{2} 0.9131 h_{22, t-1}$

Brent (1) vs. QAT (2): Conventional

$h_{11, t}=0.0004+0.0410 u_{1, t-1}^{2}+0.9572 h_{11, t-1}$

$h_{22, t}=0.0001+0.0464 u_{2, t-1}^{2}+0.9533 h_{22, t-1}$

Brent (1) vs. QAT (2): Islamic

$h_{11, t}=0.0061+0.1162 u_{1, t-1}^{2}+0.0000 h_{11, t-1}$

$h_{22, t}=0.0000+0.0679 u_{2, t-1}^{2}+0.9319 h_{22, t-1}$

Brent (1) vs. UAE (2): Conventional

$h_{11, t}=0.0003+0.0470 u_{1, t-1}^{2}+0.9514 h_{11, t-1}$

$h_{22, t}=0.0043+0.0567 u_{2, t-1}^{2}+0.0268 h_{22, t-1}$

Brent (1) vs. UAE (2): Islamic

$h_{11, t}=0.0004+0.0433 u_{1, t-1}^{2}+0.95472 h_{11, t-1}$

$h_{22, t}=0.0008+0.0568 u_{2, t-1}^{2}+0.9273 h_{22, t-1}$ 
Jihed Majdoub is an Associate Professor of finance at the Institut Supérieur de Gestion de Tunis (University of Tunis) since September 2011. He is also a fellow at the Laboratory for Research on Quantitative Development Economics at the Faculty of Economics and Management of Tunis. He received his $\mathrm{PhD}$ in Finance from the University of Cergy-Pontoise in France in 2010. He has published a number of co-authored chapters in books. He has also published several papers in international journals such as the North American Journal of Economics and Finance, Journal of Computations \& Modeling, and Emerging Markets Review, among others. His research interests cover international diversification, financial econometrics, and behavioral finance.

E-mail: jihed.majdoub@isg.rnu.tn

Walid Mansour is an Advisor at the Financial Sector Development Department of the Saudi Arabian Monetary Authority (SAMA). He has research and consultancy experience in the field of Islamic finance, investments, and Islamic financial products development. He has published several articles in international journals. $\mathrm{He}$ holds a PhD in finance and a post-doctoral diploma from Kansas University.

E-mail: walid.mansour@fulbrightmail.org

Islem Arrak is a PhD student in finance at the University of Sousse in Tunisia. She has research experience at the Institut Supérieur de Finances et de Fiscalité since 2013. Her research interests cover financial markets, financial econometrics, Islamic finance, and corporate finance.

E-mail: islemarrak@rocketmail.com 


\title{
امتداد التقلب بين مؤشرات الأسهم وأسعار النفط الخام: شـواهد من الأسـواق الإسلامية موسية
}

\author{
جهاد مجدوب \\ المعهل العالي للإدارة، جامعة تونس، تونس هوتس \\ وليد منصيور \\ مؤسسة النقلد العربي السعودي مليوري \\ إسلام أراك \\ المعهد العالي للاقتصياد والتمويل، جامعة سيوستة، تونس
}

المستخلص. تدرس هذه الورقة امتداد التقلبات بين أسواق الأسهم الإسلامية وأسعار النفط

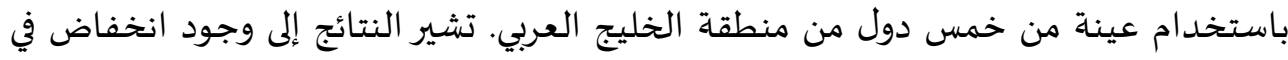
امتداد التقلبات، خاصة بالنسبة للسوق السعودي. ويمكن تفسير ذلك، في رأينا، من حيث السمات المميزة لخصائص الوساطة المالية الإسلامية. فهي تتمتع بقدرة أكبر على التخفيف من

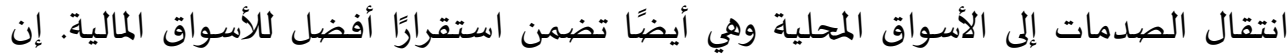

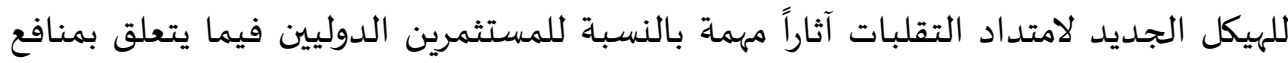

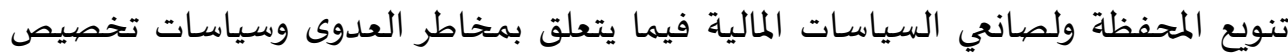
المحفظة.

الكلمات الرئيسية: امتداد التقلبات، مجلس التعاون لدول الخليج، سعر النفط، التمويل الإسلامي. 
